\title{
ALTERNATIVE FORMULATIONS OF SYNTHETIC PYRETHROIDS FOR THE CONTROL OF ADULT GRASS GRUB
}

\author{
D.R. LAUREN, R.F. HENZELL, B.N. SMITH* \\ AND D.P.F. GRAHAM* \\ Soil and Plant Research Station \\ Ruakura Agricultural Research Centre, MAF, Hamilton \\ *ICI Tasman Ltd., Hamilton
}

\begin{abstract}
Summary
Microencapsulation has been shown to significantly $(P<0.05)$ increase the field life of both permethrin and cypermethrin in trials against adult grass grub (Costelytra zealandica). This has allowed good control to be achieved with microencapsulated permethrin from only two sprays at 0.2 $\mathrm{kg} / \mathrm{ha}$ applied to cover the major mating flight period, and has allowed a more widely spaced ( 8 day interval) three-spray programme to be as efficient as the standard programme (three sprays at six day intervals). Another synthetic pyrethroid, decamethrin, gave good control at $0.02 \mathrm{~kg} / \mathrm{ha}$.
\end{abstract}

\section{INTRODUCTION}

In the last 2 years good results have been reported using synthetic pyrethroid insecticides against grass grub adults as a means of reducing subsequent larval numbers (Henzell and Lauren 1977; Pottinger et al 1977, 1978; Lauren et al 1978). At present, the minimum effective rates of the two pyrethroids cypermethrin and permethrin are about 0.1 and $0.2 \mathrm{~kg} / \mathrm{ha}$ respectively. Laboratory bioassays (Henzell and Lauren 1978; Lauren et al 1979) have shown that for field use at these rates, three applications at 6 day intervals are required to maintain a toxic cover on the foliage over the major grass grub mating period; a period of 14 to 18 days (Henzell et al 1978). However, to obtain optimum results, there is also a timing requirement for the spray programme (Lauren et al 1978; East et al 1979) and a starting delay of only 5 days from the ideal, or a premature start of more than about 6 days significantly reduces the level of control achieved. It is important to obtain the maximum possible level of control, since it is probable that less effective treatments would require retreatment more frequently to maintain the grass grub population below damaging levels.

The need for accurate timing of the first spray is a requirement enforced by the short active life of the currently available pyrethroid formulations, and the associated need to keep the number of applications to a minimum. There would be a considerable advantage if alternative formulations and/or chemicals could be found that would have a longer biologically active field life. Spray programmes starting several days before the present ideal with applications spaced at 8 or 9 day intervals would reduce the accuracy required for commencing the programme, while also accommodating moderate within paddock or within farm differences in beetle flight times caused by topography. Alternately, such formulations could potentially save in treatment costs. For example, two applications at 9 day intervals may give adequate cover over the 18 day major mating period, or lower application rates may retain activity for the 6 day interval

Proc. 32nd N.Z. Weed and Pest Control Conf. 


\section{Pasture Pests}

required for the standard three-spray programme. Henzell and Lauren (1978) and Lauren et al (1979) have recently shown by bioassay, that microencapsulation can significantly increase the active field life of permethrin.

The aim of this trial was to compare the relative effectiveness for grass grub control of standard EC formulations of cypermethrin and permethrin with that of microencapsulated formulations of the same two chemicals. The reportedly more active pyrethroid, decamethrin (Elliott $e t$ al 1978) was also compared with the other four candidates.

\section{Pre-treatment}

\section{METHODS}

The trial site was on a dairy farm on rolling country $30 \mathrm{~km}$ south of Hamilton. Plots $(9 \times 9 \mathrm{~m})$ were placed in rows with a $3 \mathrm{~m}$ buffer between all adjacent plots. In September, 1978, 16 soil cores (Kain and Young 1975) (10 cm dia.) were taken in a random grid pattern from the inner $5 \times 5 \mathrm{~m}$ of each plot, and hand sorted in the field. Plots with a population below $32 / \mathrm{m}^{2}$ were resampled to give a more precise estimate of the population. Eighty four plots with populations in the range $21-167$ larvae or pupae $/ \mathrm{m}^{2}$ were chosen for use, with 21 of these in a block on a slope, and the rest, blocked with respect to population, on the flat. The paddock was grazed up to October 11,1978, and had a pasture height of 3 $-6 \mathrm{~cm}$ at the commencement of the trial period.

\section{Monitoring}

Grass grub mating flight activity over the trial area was monitored as by Lauren et al (1978). Grass grub development during the flight period was assessed weekly by taking 100 soil cores at random from the untreated buffer zones.

\section{Treatments}

There were four different spray programmes as described below. Each of five candidate insecticide formulations was used under each of these four spray programmes, to give a total of 20 different treatments (Table 1). There were four replicates for each treatment plus the untreated controls.

Spray dates were determined from the previous year's (1977) mating flight data as described by Lauren et al (1978). (The major mating period in 1977 occurred within the 18 day period from October 18 to November 4, and this was repeated in 1978 with the cumulative percentage catch increasing from $3-74 \%$ in this period. In 1978, the percentage of mated females found in the soil increased from $0 \%$ on October 18 , to about $10 \%$ on October 24 , and to $80-90 \%$ on October 30).

Programme 1: Three applications of the higher rates shown in Table 1 at 6 day intervals, with the first application on October 18. This is the standard ideal programme as described by Lauren et al (1978). Treatments $1,5,9,13,17$.

Programme 2: Three applications at half the rate used in programme 1 at 6 day intervals with the first application on October 18. This attempts to use a low rate in the standard spray programme. Treatments $2,6,10,14,18$

Programme 3: Two applications at the higher rates as in programme 1 at 9 day intervals, with the first application on October 18. This attempts to cover the major mating period with two sprays. Treatments $3,7,11,15,19$. 


\section{Pasture Pests}

Programme 4: Three applications at the higher rates as in programme 1 at 8 day intervals, with the first application on October 12. This attempts to cover a longer period ( 24 days) with a three spray programme. Treatments 4,8,12,16,20.

\section{Chemicals and Equipment}

Cypermethrin (250 g/litre EC, batch number JF 6670 D107), microencapsulated (micro-) cypermethrin $(200 \mathrm{~g} /$ litre, batch number ERO A $083378 \mathrm{JH})$, permethrin $(500 \mathrm{~g} /$ litre EC, batch number ADY M1815/B), and microencapsulated permethrin $(200 \mathrm{~g} /$ litre, batch number ERO AR $083378 \mathrm{JH}$ ) were supplied by ICI Plant Protection Division, Jealott's Hill Research Station, Bracknell, England, and decamethrin ( $25 \mathrm{~g} /$ litre EC, batch number 37 T 0831) was supplied by Procida/Roussel Uclaf, Saint-Marcel, France.

The spray equipment used was described by Lauren et al (1978).

Table 1: Summary of treatments and resulting reductions in the subsequent grass grub larval populations.

\begin{tabular}{|c|c|c|c|c|c|}
\hline $\begin{array}{l}\text { Treatment } \\
\text { number }\end{array}$ & $\begin{array}{l}\text { Chemical and } \\
\text { rate }(\mathrm{kg} / \mathrm{ha})\end{array}$ & $\begin{array}{l}\text { First spray } \\
\text { date }\end{array}$ & $\begin{array}{l}\text { No. of } \\
\text { sprays }\end{array}$ & $\begin{array}{c}\text { Spray } \\
\text { interval } \\
\text { (days) }\end{array}$ & $\begin{array}{c}\text { Control* } \\
(\%)\end{array}$ \\
\hline $\begin{array}{l}1 \\
2 \\
3 \\
4\end{array}$ & $\begin{array}{l}\text { cypermethrin EC } \\
0.1 \\
0.05 \\
0.1 \\
0.1\end{array}$ & $\begin{array}{l}\text { Oct } 18 \\
\text { Oct } 18 \\
\text { Oct } 18 \\
\text { Oct } 12\end{array}$ & $\begin{array}{l}3 \\
3 \\
2 \\
3\end{array}$ & $\begin{array}{l}6 \\
6 \\
9 \\
8\end{array}$ & $\begin{array}{l}82 \\
77 \\
66 \\
78\end{array}$ \\
\hline $\begin{array}{l}5 \\
6 \\
7 \\
8\end{array}$ & $\begin{array}{c}\text { cypermethrin micr } \\
0.1 \\
0.05 \\
0.1 \\
0.1\end{array}$ & $\begin{array}{l}\text { Oct } 18 \\
\text { Oct } 18 \\
\text { Oct } 18 \\
\text { Oct } 12\end{array}$ & $\begin{array}{l}3 \\
3 \\
2 \\
3\end{array}$ & $\begin{array}{l}6 \\
6 \\
9 \\
8\end{array}$ & $\begin{array}{l}69 \\
59 \\
71 \\
76\end{array}$ \\
\hline $\begin{array}{r}9 \\
10 \\
11 \\
12\end{array}$ & $\begin{array}{l}\text { permethrin EC } \\
0.2 \\
0.1 \\
0.2 \\
0.2\end{array}$ & $\begin{array}{l}\text { Oct } 18 \\
\text { Oct } 18 \\
\text { Oct } 18 \\
\text { Oct } 12\end{array}$ & $\begin{array}{l}3 \\
3 \\
2 \\
3\end{array}$ & $\begin{array}{l}6 \\
6 \\
9 \\
8\end{array}$ & $\begin{array}{l}89 \\
81 \\
60 \\
77\end{array}$ \\
\hline $\begin{array}{l}13 \\
14 \\
15 \\
16\end{array}$ & $\begin{array}{l}\text { permethrin micro } \\
0.2 \\
0.1 \\
0.2 \\
0.2\end{array}$ & $\begin{array}{l}\text { Oct } 18 \\
\text { Oct } 18 \\
\text { Oct } 18 \\
\text { Oct } 12\end{array}$ & $\begin{array}{l}3 \\
3 \\
2 \\
3\end{array}$ & $\begin{array}{l}6 \\
6 \\
9 \\
8\end{array}$ & $\begin{array}{l}92 \\
64 \\
84 \\
90\end{array}$ \\
\hline $\begin{array}{l}17 \\
18 \\
19 \\
20\end{array}$ & $\begin{array}{c}\text { decamethrin EC } \\
0.02 \\
0.01 \\
0.02 \\
0.02\end{array}$ & $\begin{array}{l}\text { Oct } 18 \\
\text { Oct } 18 \\
\text { Oct } 18 \\
\text { Oct } 12\end{array}$ & $\begin{array}{l}3 \\
3 \\
2 \\
3\end{array}$ & $\begin{array}{l}6 \\
6 \\
9 \\
8\end{array}$ & $\begin{array}{l}83 \\
63 \\
85 \\
78\end{array}$ \\
\hline 21 & untreated & - & - & - & 0 \\
\hline
\end{tabular}

* \% reduction in larval population of treated plots compared to untreated plots. The average population in untreated plots was $138 / \mathrm{m}^{2}$. 
Pasture Pests

\section{Weather for spray application}

Due to the wet and windy weather prevailing for about three consecutive days in the early part of the spray period, some applications were made in unfavourable conditions. Applications on October 18 and 20 were made to partly wet grass and under occasional light showers. A warm breeze meant that the fine spray droplets dried off quickly but the pasture was never completely dry. On both days, heavier intermittent showers began about 30 minutes after the final application, and continued for several hours before heavy rain set in. On all other spray days, the applications were made to dew-covered pasture but under good drying conditions. It was felt that a test of the various synthetic pyrethroids under these varied conditions would be useful, since if they are to be used on a large scale for adult grass grub control, favourable weather conditions will not always be experienced.

\section{Post-treatment}

The paddock was cut for silage on November 20,1978, and then grazed $(12 \mathrm{~h})$ by the dairy herd (46 cows/ha) on an average 12 day rotation.

Treatment effects were assessed in March, 1979, as described by Lauren et al (1978).

\section{RESULTS}

All treatments (Table 1) gave a significant reduction in the subsequent larval population $(\mathrm{P}<0.01)$. Overall, micro-permethrin was significantly better than all other formulations $(\mathrm{P}<0.05)$, while micro-cypermethrin was significantly worse than all other formulations $(\mathrm{P}<0.05)$. There was about twice the resultant population under micro-cypermethrin as under micro-permethrin, with cypermethrin, permethrin and decamethrin EC s having intermediate numbers.

Overall, spray programme 1 was significantly better than all others $(\mathrm{P}<0.05)$, while programme 2 , at half rates, was significantly worse than all the higher rate programmes $(\mathrm{P}<0.05)$. The lower rate programme tended to have twice the resulting population as programme 1 , with programmes 3 and 4 intermediate. There was also a significant effect $(\mathrm{P}<0.05)$ that both microencapsulated formulations did relatively better (compared to programme 1) on programmes 3 and 4 (those with wider spray intervals) than did the standard EC formulations.

\section{DISCUSSION}

This trial has shown that there is scope in the field of formulation technology for an improvement in the field life of the synthetic pyrethroid insecticides. This aspect could be particularly important in deciding whether these chemicals are to find a use in the field of adult grass grub control, since, apart from the uncertain cost, the frequency of spraying and the need for precise timing of the spray programme are two of the major drawbacks of the technique.

The results obtained with the higher rate of micro-permethrin (treatments 15 and 16) showed that longer spray intervals are possible. The fact that a programme of three sprays spaced at 8 day intervals to cover a 24 day period can give a high level of control, is of particular relevance to more hilly areas where flight activity is generally more protracted (Henzell et al 1978). Also, the improved level of control of the two-spray programme over the equivalent programme with the EC formulation showed that with a further increase in field life, good control could be expected from only two sprays. However, in any programme with just two sprays, it is likely that accurate timing would be essential. The 


\section{Pasture Pests}

low rate of micropermethrin, on the other hand, was unsatifactory, and this could be explained by the expected reduced coverage of the foliage with active point sources (microcapsules) compared with the higher rate.

The efficiency of micro-cypermethrin was disappointing, and was generally lower than that obtained with the EC formulation. This effect is likely to be a fault of the particular formulation involved rather than the basic concept of microencapsulation. It is possible that the polymer wall used for these microcapsules did not allow an adequate diffusion rate of cypermethrin to give a sufficiently high activity on the outer surface. This explanation is consistent with the field results and with bioassay data (Henzell et al 1979). The bioassays showed that although the activity of micro-cypermethrin was initially lower than that of the EC formulation, it declined at a slower rate. This meant that after $8-9$ days weathering in the field, the microencapsulated formulation was more active than the same rate of the EC.

The other chemical, decamethrin, performed better in the field trials than was expected from bioassay results (Henzell et al 1979). The bioassays suggested that a rate of about $0.035 \mathrm{~kg} / \mathrm{ha}$ would be needed to give an activity equivalent to $0.1 \mathrm{~kg} / \mathrm{ha}$ of cypermethrin EC or $0.2 \mathrm{~kg} / \mathrm{ha}$ of permethrin EC. In fact, while $0.01 \mathrm{~kg} / \mathrm{ha}$ was obviously too low, a rate of $0.02 \mathrm{~kg} / \mathrm{ha}$ gave results not significantly different to those achieved with the mentioned rates of the other two chemicals. Further evaluation of this new product is obviously required.

In conclusion, these trials represent the third successive year we have obtained high levels of grass grub control with synthetic pyrethroid applications during the major mating period (Henzell and Lauren 1977; Lauren et al 1978). While the procedure for obtaining satisfactory control is somewhat more sophisticated than that employed with larvicides, the fact that some of the early applications in this season's work were made under unfavourable conditions suggests that good control is possible provided reasonable care is taken over such details as timing, spray interval, and the weather conditions for application. In addition, the extended coverage available from a three-spray programme with micro-permethrin means that reliable results should be possible over a variety of sites with different terrains.

\section{ACKNOWLEDGEMENTS}

We thank Mr T. O'Regan for the use of his property, and Dr N. Cox for statistical evaluation of the results. We also thank C.H. Parker, R.J. Townsend and S.J. Rowe for technical assistance, and Messrs R.P. de Borst and M.S. Venning of N.Z. Farmers' Fertilizer Co. for assistance with post-treatment sampling.

\section{REFERENCES}

East, R., Henzell, R.F. and Lauren, D.R., 1979. Timing of cypermethrin applications against grass grub adults. Proc. 32nd N.Z. Weed and Pest Control Conf.:

Elliott, M., Janes, N.F. and Potter, C., 1978. The future of pyrethroids in insect control. Ann. Rev. Entomol. 23: 443-69.

Henzell, R.F. and Lauren, D.R., 1977. Control of grass grub adults with synthetic pyrethroids. Proc. 30th N.Z. Weed and Pest Control Conf: $211-6$.

Henzell, R.F. and Lauren, D.R., 1978. Contact activity of synthetic pyrethroids against adult grass grub, Costelytra zealandica (White). Pestic. Sci.: in press.

Henzell, R.F., Lauren, D.R. and Cox, N.R., 1978. Monitoring grass grub flight with sex attractant traps. Proc. 2nd Australasian Conf. of Grassland Invertebrate Ecology: in press. 


\section{Pasture Pests}

Henzell, R.F., Lauren, D.R. and du Toit, G.D.G., 1979. Insecticides for the control of adult grass grub, II. Further tests with various synthetic pyrethroid formulations. Proc. 32nd N.Z. Weed and Pest Control Conf:

Kain, W.M. and Young, J., 1975. Population studies of Costelytra zealandica (White). I. A soil sampler suitable for sampling pastureland. N.Z. J. Exp. Agric. 3: 177-80.

Lauren, D.R., Henzell, R.F. and Yortt, M.L., 1978. The importance of application time when synthetic pyrethroids are used to control adult grass grub. Proc. 31st N.Z. Weed and Pest Control Conf.: $154-9$

Lauren, D.R., Henzell, R.F. and du Toit, G.D.G., 1979. Insecticides for the control of adult grass grub Costelytra zealandica (White). I. Chemical and biological field life of various synthetic pyrethroid formulations. N.Z. J. Agric. Res. : in press.

Pottinger, R.P., East, R., Welsh, R.D., Stratton, A.E. and Maxwell, B.C., 1977. Evaluation of cypermethrin for control of adult grass grub. Proc. 30th N.Z. Weed and Pest Control Conf.: 217-21.

Pottinger, R.P., Welsh, R.D., East, R. and Stratton, A.E., 1978. Control of grass grub adults with cypermethrin. Proc. 2nd Australasian Conf. of Grassland Invertebrate Ecology: in press. 